\title{
Regeneration and Micropropagation Systems of (Stevia rebaudiana) var. sponti
}

\author{
Ouf A,A 1, Faiza M.A El Tawel²,Yusreya H. Tawfik 3
}

\begin{abstract}
In order to establish an effective regeneration system of Stevia (Stevia rebaudiana) var. sponti, different concentrations of phytohormones were added to MS basal medium individually or in combination with (IAA, BAP and NAA) as callus induction media. The obtaining results indicated that MS basal medium which containing $0.5 \mathrm{mg} / \mathrm{l}$ of NAA and 0.5 BAP was the most efficient and effective medium for callus induction.

For shoot regeneration, different recombination of phytohormones were used, addition of NAA $(0.1 \mathrm{mg} / \mathrm{l})$ and BAP $(1.0 \mathrm{mg} / \mathrm{l})$ to MS basal medium under light condition caused high increase in shooted calli percentage.

Vigor root system was developed after the addition of 3 $\mathrm{mg} / \mathrm{l}$ of IBA to MS basal medium, while the addition of high concentration of sucrose $(80 \mathrm{~g} / \mathrm{L})$ found to be ineffective factor for root regeneration and growth. Micropropagation system was performed by exposure of axillaries and terminal buds to solid MS medium which contained 0.1 IAA and 1.0 BA. Then, clusters were cut into small number of plantlets in MS liquid media without any hormone. This method was found to be more effective than using hormonal medium for micropropagation.
\end{abstract}

\section{INTRODUCTION}

Stevia rebaudiana is a herb belong to family Asteraceae family indigenous the higher elevations of Northern Paraguay near the Braziliam borders (Soejarto et al., 1983). This plant has gained importance as a crop for the pharmaceutical and food industries as a result of non-caloric sweeteners extracted from its leaves, mainly stevioside, somatic embryogenesis has been described for more than a hundred plant species (Terzi and Loschiavo, 1990), but the number of reports of somatic embryogenesis among members of the Asteraceae family is still low (May and Trigiano, 1990). The development of protocols for regeneration of Stevia rebaudiana via somatic embryogenesis is important as well as the clonal propagation technique of this plant, or as explant material for protoplast isolation and regeneration (Puite, 1992).

The main goal of this investigation is: (1) to

\footnotetext{
${ }^{1}$ Laboratory of Biotechnology. Sugar crops Res. Inst., Agric. Res Center.ac. Agric., Saba basha, Alex. Univ.

2 Plant Physiology Department. Sugar crops Res. Inst., Agric. Res. Center

3 Plant Breeding Department, Sugar crops Res. Inst., Agric. Res. Center Received August 29, 2007, Accepted September 30, 2007
}

develop a protocol for the induction of somatic embryogenesis from leaf explants of Stevia rebaudiana. Also, to establish a most effective regeneration system required for somaclonal variation. (2) To achieve an efficient micropropagation system for the improved plants.

\section{MATERIALS AND METHODS}

\section{Plant material}

Stevia (Stevia rebaudiana var. sponti) was used as explants donor for this work.

\section{Methods:}

\section{1- Tissue culture:}

\section{a- Callus induction}

Young leaves of Stevia (Stevia rebaudiana var. sponti) were cut, then sterilized in sodium hypochlorite solution $2 \%$ for $20 \mathrm{~min}$. and washed twice in sterilized distilled water. Small pieces (about $1 \mathrm{~cm}^{2}$ ) of leaves were exposed to callus induction media which contained basal MS medium with different hormonal supplements (table 1). Finally, cultures were maintained in incubator in the dark at $25^{\circ} \mathrm{C}$ until callus production had achieved.

2, 4-D: 2, 4- Dichlorophynoxy acetic acid, NAA: Naphhalene acetic acid, BAP: Benzyl amino purine.

\section{a- Regeneration}

\section{- shoot regeneration:}

Embryogenic calli were transferred to shoot regeneration medium MS supplemented with $30 \mathrm{~g}$ sucrose and phytohormones $(0.1,0.5$ and $1.0 \mathrm{mg} / \mathrm{L}$ of NAA and $0.1,0.5$ and $1.0 \mathrm{mg} / \mathrm{L}$ of BAP).

\section{- Root regeneration:}

Two kinds of media were applied, the first composed of MS basal medium supplemented with $30 \mathrm{~g}$ sucrose and contained different concentrations of IBA (Indole butaric acid) hormone (1, 2, 3 and $4 \mathrm{mg} / \mathrm{L})$. The second is MS medium (hormone free) that contained high concentration of sucrose $(80 \mathrm{~g} / \mathrm{L})$ 
and it was used to induce roots.

Table 1. Different callus induction media.

\begin{tabular}{ccccc}
\hline & \multicolumn{4}{c}{$\begin{array}{c}\text { Concentration (mg/l) and } \\
\text { medium designation }\end{array}$} \\
\cline { 2 - 5 } added to MS & M1 & M2 & M3 & M4 \\
\hline BAP & 0.0 & 0.1 & 0.5 & 0.5 \\
$2,4-D$ & 0.0 & - & 0.5 & - \\
NAA & 0.0 & 0.1 & 0.5 & 0.5 \\
Sucrose & $30 \mathrm{~g} / 1$ & $30 \mathrm{~g} / 1$ & $30 \mathrm{~g} / 1$ & $30 \mathrm{~g} / 1$ \\
Phytagel & $6 \mathrm{~g}$ & $6 \mathrm{~g}$ & $6 \mathrm{~g}$ & $6 \mathrm{~g}$ \\
pH & 6.8 & 6.8 & 6.8 & 6.8 \\
\hline
\end{tabular}

C- Micropropagation:

Terminal and auxiliary buds were experimented for solid MS medium which contained 0.1 IAA and 1.0 BA in dark for 3 days then transferred to the light (about $1500 \mathrm{Lux})$ under photosynthesizing $16 \mathrm{~h}$ light and $8 \mathrm{~h}$ dark at $27 \mathrm{C}$

\section{2- Plant Multiplication:}

Growing clusters (about $3 \mathrm{~cm}$ height) were transferred into liquid medium without any addition of hormones (hormone free). The obtaining cultures were

cut into 2-3 plant and distributed into new gars contains fresh multiplication medium. This step is replicated every two weeks.

\section{RESULTS AND DISCUSSION}

\section{Callus induction:}

Embryogenic white calli with compact cells in globular forms and capable of plant regeneration were produced (Fig. 1). Interestingly, hormonal contents in cultural medium were the main factor influenced callus induction and rate of embryogenic type. The present results revealed that the M4 medium (which contained $0.5 \mathrm{mg} / \mathrm{l}$ of NAA and $0.5 \mathrm{BAP}$ ) was the most efficient for this purpose. The dependence of embryogenic calli on hormonal content was demonstrated in many several works (Filho et al., 2000, Sivaram and Mukunda., 2003).

\section{Maintenance of embryogenic calli:}

Subculture of embryogenic calli could be maintained on M4 medium for more than two weeks with the maintaining of their embryogenic ability. Embryogenic calli could be maintained for three months on callus induction medium. The same results were reported by Sanders (1997).
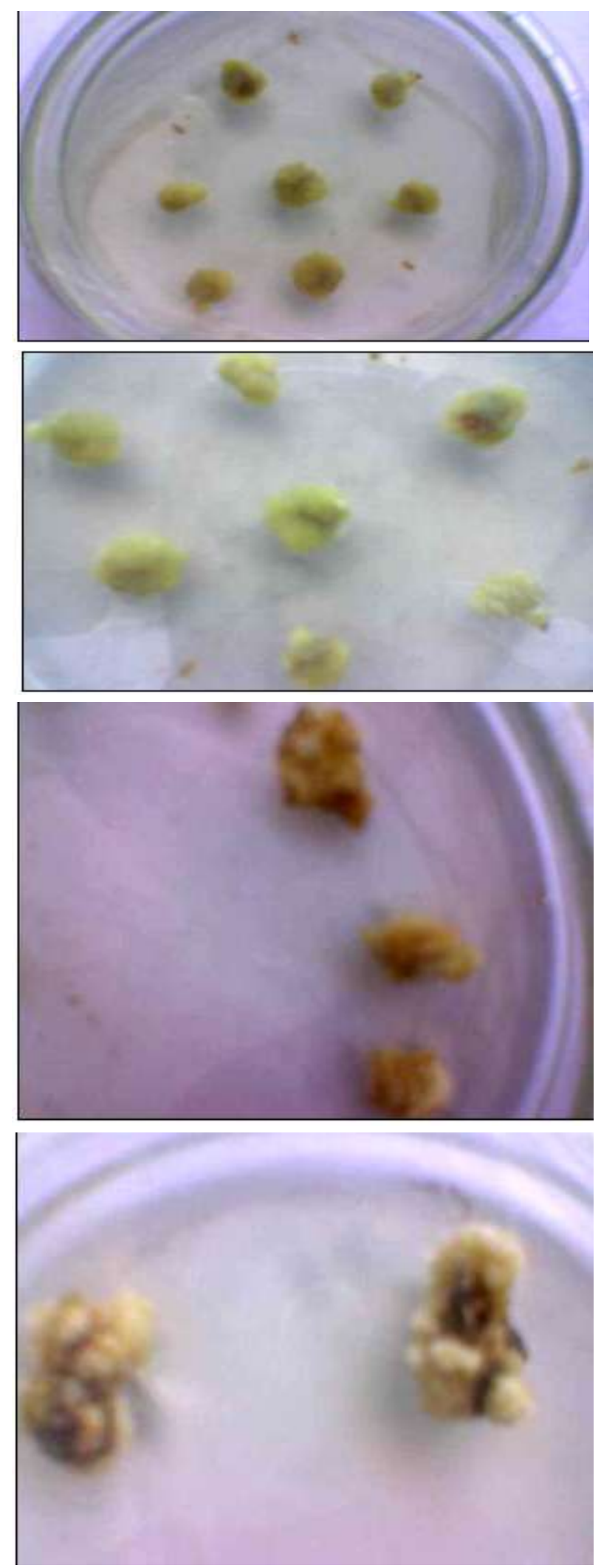

Figure 1: Embryogenic calli proliferation. 
Table 2. illustrates the percentage of calli induction in different types of medium under different hormonal concentrations.

\begin{tabular}{ccccc}
\hline Medium Types & M1 & M2 & M3 & M4 \\
\hline $\begin{array}{c}\text { Hormonal } \\
\text { concentrations }\end{array}$ & $0.0 \mathrm{mg} / \mathrm{l}$ & $0.1 \mathrm{mg} / \mathrm{l}$ & $0.5 \mathrm{mg} / \mathrm{l}$ & $0.5 \mathrm{mg} / \mathrm{l}$ \\
2,4-D, BAP and NAA & BAP and 0.1 NAA & $2,4-\mathrm{D}, \mathrm{BAP}$ and NAA & BAP and 0.5 NAA \\
Calli Percentage & 55 & 64 & 72 & 88 \\
\hline
\end{tabular}

\section{Regeneration:}

Shoot were producing by addition of NAA $(0.1 \mathrm{mg} / \mathrm{l})$ and BAP $(1.0 \mathrm{mg} / \mathrm{l})$ to MS basal medium under light condition (Fig. 2). It was noticed that different root system were produced after different concentration of IBA added, increasing in root induction and root growth was detected for addition of $3 \mathrm{mg} / \mathrm{l}$ of IBA (Fig. 3). Similar findings was reported by Barathi et al., 2003 and Sivaram and Mukunda (2003) by adding similar hormones to MS medium to produce shoot an d root system. Our obtaining results were in agreement of Barathi et al., 2003 established a successful multiplication system for stevia based on culture on free hormone medium. Contrary to results reported by Scoot et al., (2000) high concentration of sucrose had not induced root on the shooted calli of this varity.

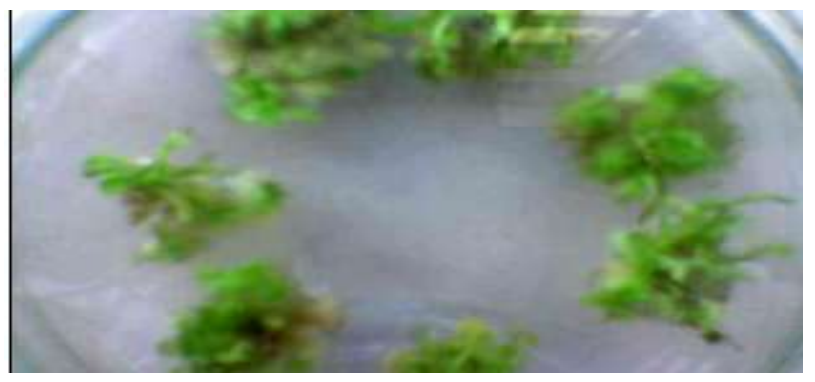

(a)

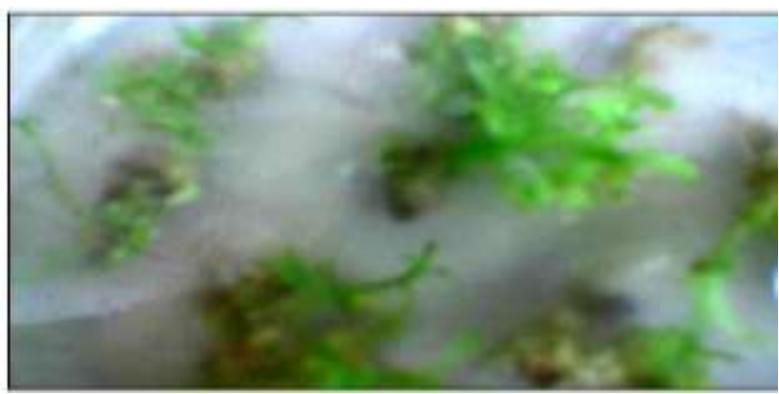

(b)

Figure 2. Shoot regeneration: a- shoot formation. b- shoot growth.

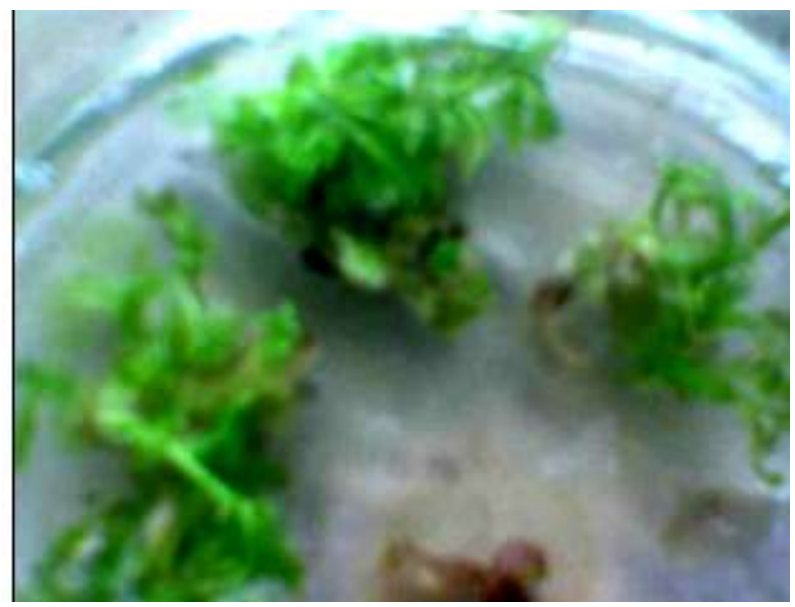

(a)

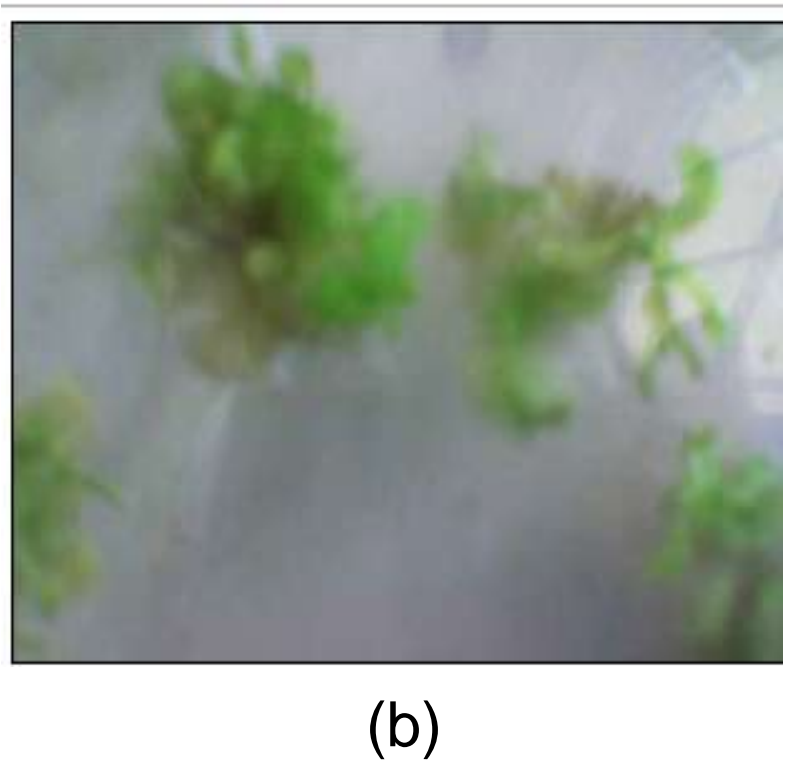

Figure 3. Root regeneration:

a- Root formation.

b- Root growth. 

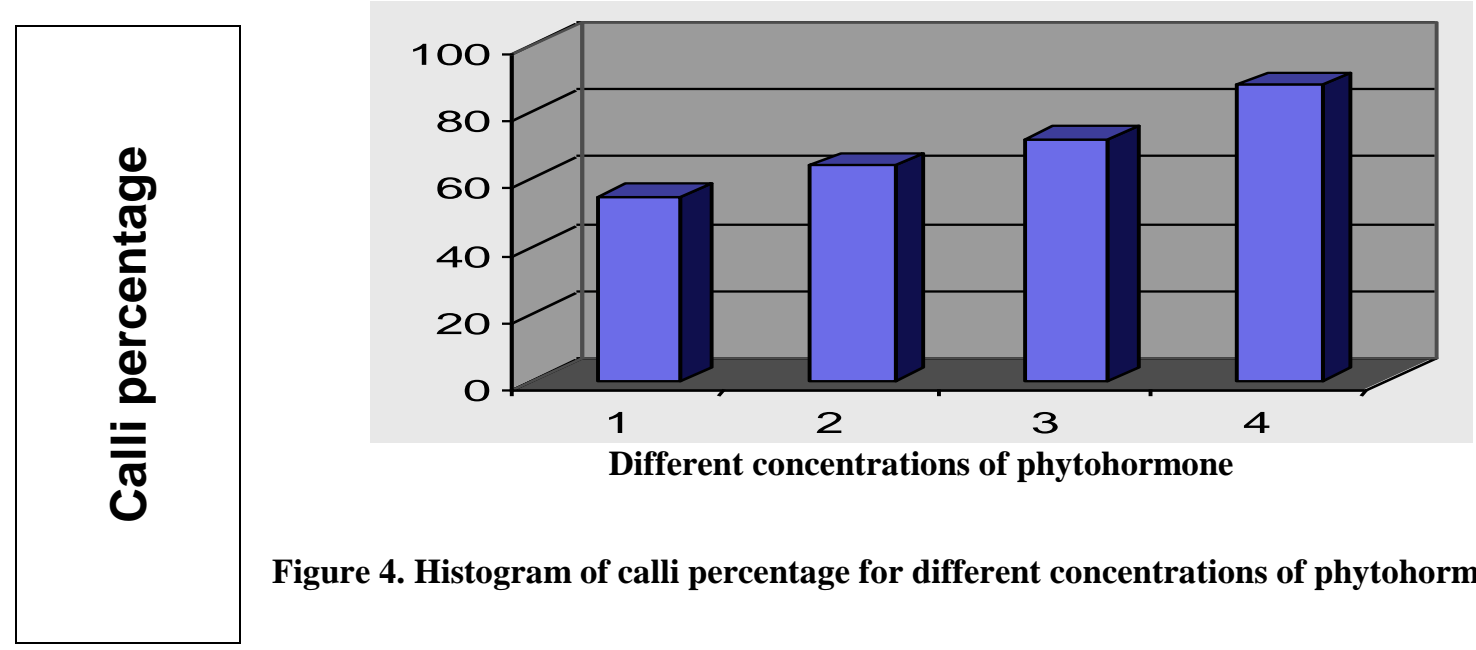

Figure 4. Histogram of calli percentage for different concentrations of phytohormones.

$$
\begin{aligned}
& \text { 1- } 0.0 \mathrm{mg} / \mathrm{l} \text { 2, 4-D, BAP and NAA } \\
& \text { 2- } 0.1 \mathrm{mg} / \mathrm{l} \text { 2, 4-D, BAP and NAA } \\
& \text { 3- } 0.5 \mathrm{mg} / \mathrm{l} \text { 2, 4-D, BAP and NAA } \\
& \text { 4- } 1.0 \mathrm{mg} / \mathrm{l} \text { 2, 4-D, BAP and NAA }
\end{aligned}
$$
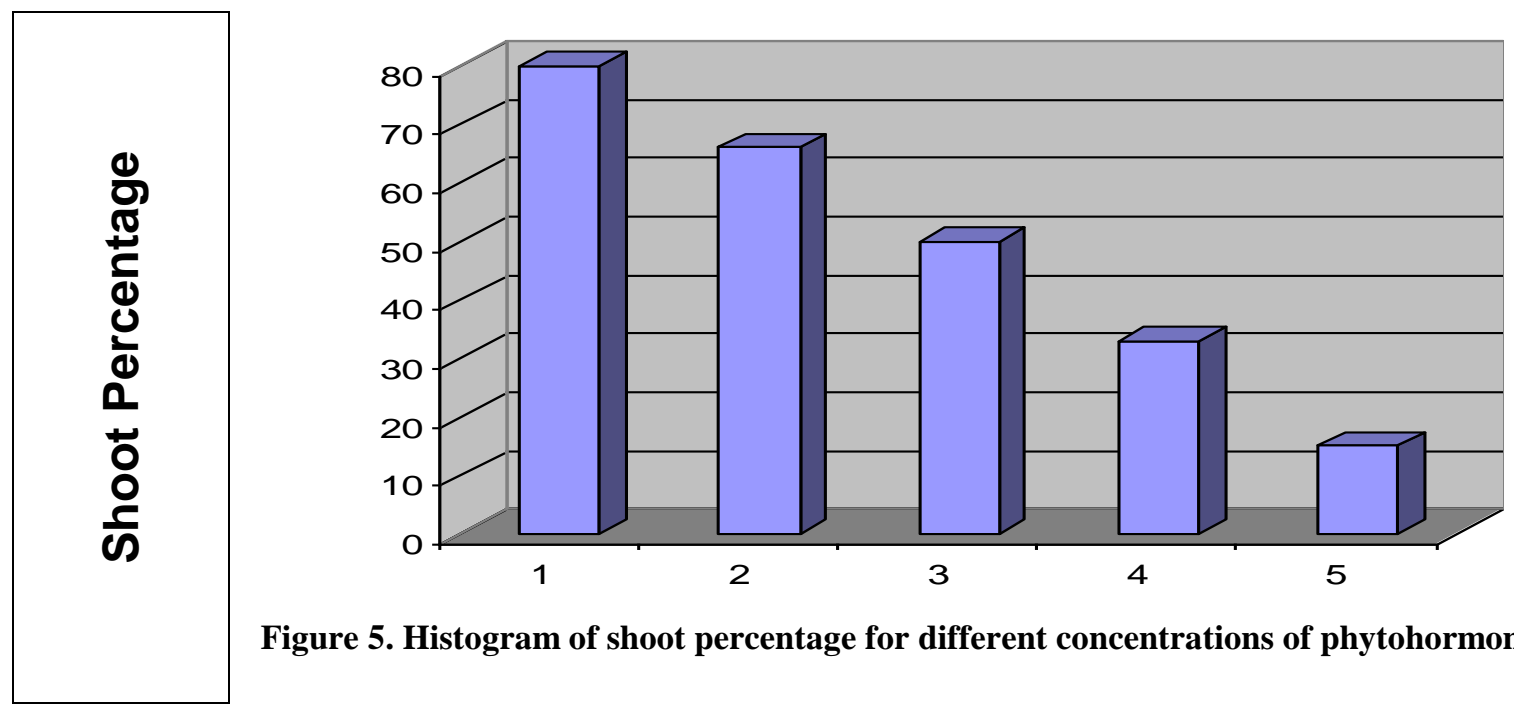

Figure 5. Histogram of shoot percentage for different concentrations of phytohormones.

Where:

1- NAA 0.1 + 1.0 BAP.

2- NAA 0.1 + 0.5 BAP.

3- NAA 0.1 + 0.1 BAP

4- NAA 0.5 + 0.1 BAP

5- NAA $1.0+0.1$ BAP 

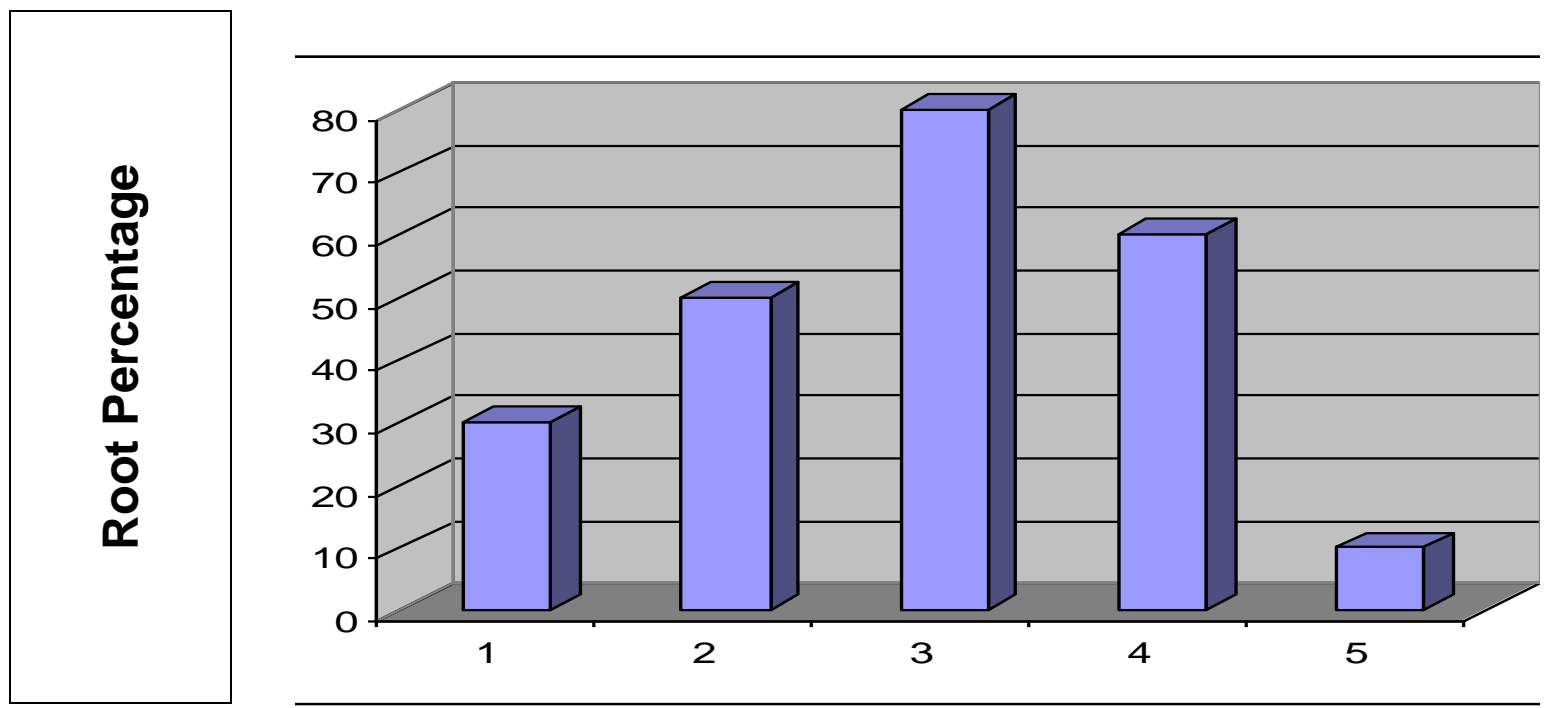

Different concentrations of IBA phytohormone

Figure 6. Histogram of root percentage for different concentrations of IBA phytohormones.

1- $1.0 \mathrm{mg} / \mathrm{l}$ of IBA + $30 \mathrm{~g}$ sucrose

2- $2.0 \mathrm{mg} / \mathrm{l}$ of IBA+ $30 \mathrm{~g}$ sucrose

3- $3.0 \mathrm{mg} / \mathrm{l}$ of IBA+ $30 \mathrm{~g}$ sucrose

4- $4.0 \mathrm{mg} / \mathrm{l}$ of IBA+ $30 \mathrm{~g}$ sucrose

5- 80 g sucrose

\section{REFERENCES}

Barathi V., Peleg K. and Ziv M. (2003). Morphological control and mensuration of potato plantlets from tissue cultures for automated micropropagation. Plant Cell Tiss. Org. Cult. 36:331-338.

Filho J.C, Hashimoto J M and Vieira L .G. (2000). Area de Ecofisiologia, Instituto Agronômico do Paraná. Canadian Jour-nal of Botany, 67:970-976.

May, R.A.and Trigiano, R.N. (1991). Somatic embryogenesis and plant regeneration from leaves of Dendranthema grandi-flora. Journal of American Society for Horticultural Science, 116(2):366-371,.

Puite, K.J. (1992). Progress in plant protoplast research. Physiolo-gia Plantarum, 85:403-410.

Sanders .C. McWilliams E.L. and Davies F.T. (1997) In vitro adventitious callus formation in Asian jasmine (Trachelospermum asiaticum). I. Comparative morphology. J. Amer. Soc. Hort. Sci. 118:902-905.
Scoot O., Lewis M., Brackpool A. \& Blakesley D. (2003).

Auxin and adventitious root initiation in Eucalyptus globulus. Abstracts VIIIth International Congress of Plant Tissue and Cell Culture.

Soejarto, D.D.; Compadre, C.; Medon, P.J. Kamath, S.K. and Kinghorn, A.D.(1983). Potential sweeting agents of plant origin. II. Field research for sweet-tasting Stevi a species. Economic Botany, 37:71-79.

Sivaram J.C and Mukunda A.A (2003). Tissue culture technique as a tool for Stevia improvement. Annual Report Research development Council, 3-9 Taiwan sugar Crop., Taiwan (In Chinease).

Terzi, M. and Loschiavo, F. (1990). Somatic embryogenesis. In: Bhojwani, S.S. Plant Tissue Culture, Applications and Limitations; Development in Crop Science. Elsevier. P.5466.

Wada, Y; Tamura, T.; kodama, T.; yamaki, T. and Uchida, Y. (1981). Callus cultures and morphogenesis of Stevia rebaudi-ana Bertoni. Yukagawa, 36(4), 215-219. 


\section{الملخص العربي}

\section{نظم اعادة التشكل و الاكثار السريع لنبات الاستيفيا (صنفisponti )}

عاطف احمد عوف، فايزة تمُحَّ ابوالفتوح الطويل، يسرية هانم توفيق

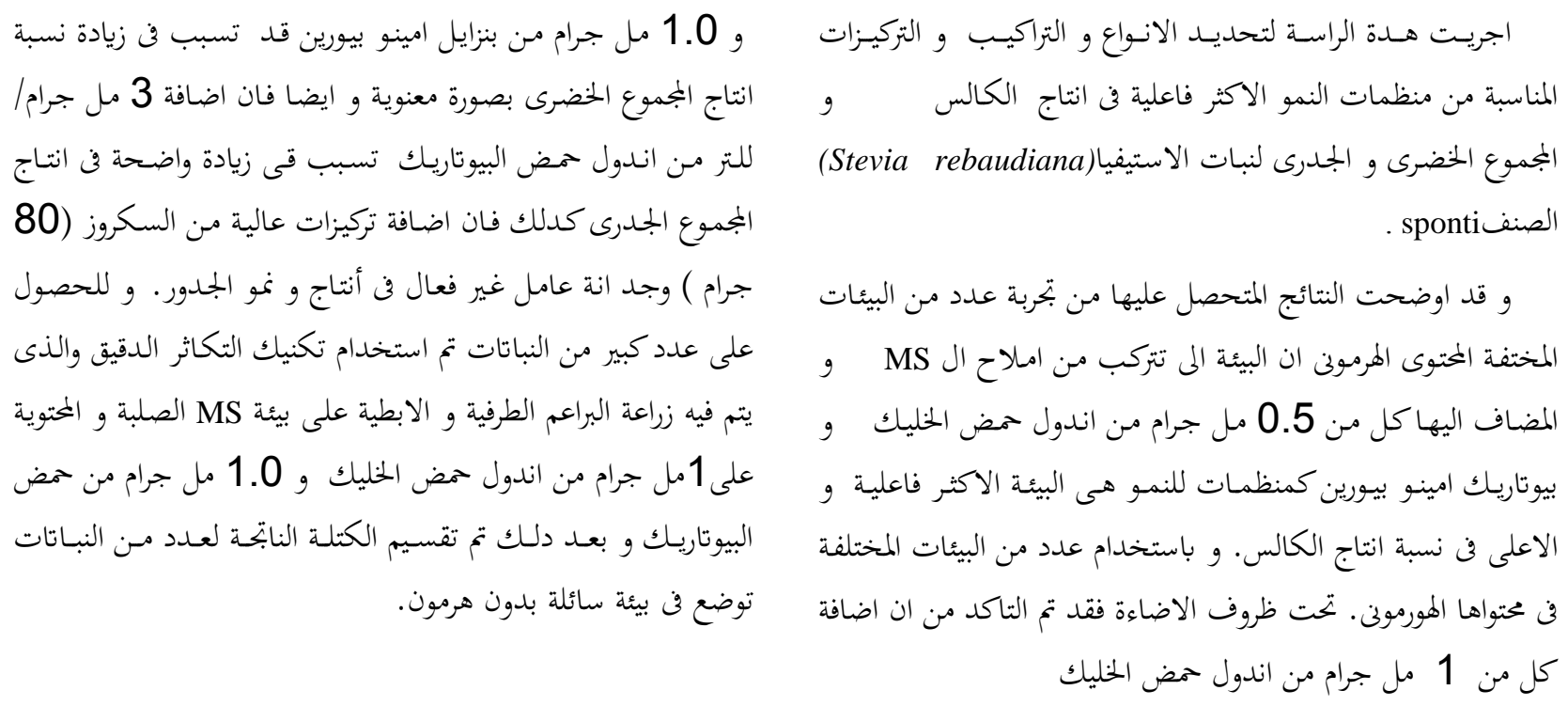

